\title{
Value-based management architecture in energy companies
}

\author{
L. M. Gitelman \\ Department of Energy and Industrial Management Systems, \\ Ural Federal University, Russia
}

\begin{abstract}
The purpose of this research is to create a concept hierarchical model demonstrating the levels of value-based management in power companies. Basic determinants and conditions are taken into account, the most important ones being the long-term "rules of the game" set by the state for the electric power industry. The next tier identifies factors that make up the intrinsic (fundamental) value of a company. The following are viewed as priority areas: strategic activities that take account of the owners' interests; implementation of effective investment programmes; building a suitable evaluation system for managerial decisions; transformation of the management structure with business units being established that focus on making value-based decisions. No less important is the "superstructure" of a company's intrinsic value that is determined by the stock market situation. This tier is the most volatile in terms of business valuation, but it also provides for a set of actions to be taken in order to meet investors interests in higher market capitalization. The impact of the identified factors on the effectiveness of value-based management was tested within the framework of the designed model in a number of energy companies between 2000 and 2013.

Keywords: electric power companies, investment appeal, conceptual model of value-based management.
\end{abstract}

\section{Introduction}

As a result of reforms and further operation, newly established Russian electric power companies have turned from being blue chips into second-tier ones, i.e., have lost in price and liquidity. Private investors owning shares in the restructured companies have now started to sell them off, even at a loss. Thus the electricity sector is becoming less attractive to investors and, consequently, is losing the chance to develop on a new technological platform. 
A typical example would be the stock price dynamics of the wholesale power generation company OJSC Enel OGK-5 over a period of seven years, starting from its IPO in October 2006 till October 2013. Over the past few years, the company's revenue has grown, so has its EBITDA (earnings before interest, taxes, depreciation, and amortization) and net profit. The company has been executing its strategy aimed at implementing investment projects and boosting the efficiency of its generation assets in the long-term perspective. However, the price per share has gone down from 0.09 dollars in 2006 to 0.0388 dollars in 2013 [2]. A question arises as to what factors have been driving the negative price dynamics.

The electric power industry, unlike many others, is highly regulated. The rules of operation in the Russian wholesale electricity and capacity market (WECM) are set by the state. For monopolistic businesses (grid companies) the regulator introduces a lot more restrictions associated with the receipt of income. Additionally, both monopolistic and competitive electric power companies are faced with two sets of objectives: commercial and social. The first one is about increasing the value of a company (its capitalization), while the second one has to do with ensuring the reliability and stability of electric power supply. It should be noted that the two objectives contradict each other. The social objective, however, has priority in terms of investment decision making. Also, global investors see substantial risk in investing in Russian companies, the areas of risk being associated with the sector's unpredictable legislative framework, specifically, the uncertainty of tariff regulation. It would only be possible to lower risks for investors through fundamental changes in managing the value of energy companies.

\section{Background to the model of value-based management in power companies}

To identify the key areas of fundamental transformation, the author has developed a conceptual hierarchical model demonstrating the levels of valuebased management in utility companies. The hierarchy means that the top tier of governance that holds the ultimate authority to make decisions is the state. For utility companies this tier is of greater importance than for joint stock companies in other industries. The next tier identifies factors that make up the intrinsic (fundamental) value of a company. No less important is the "superstructure" on top of a company's intrinsic value that is determined by the stock market situation. This tier is the most volatile in terms of business valuation, but it also provides for a set of actions to be taken in order to meet investors' interest in higher market capitalization. The value-based management architecture determines the rules of interaction among the basic elements of the model. The tiers of the conceptual model and the key aspects of value-based management are presented in Table 1. The model was built upon a series of relevant studies that were carried out under the author's guidance between 2000 and 2013 together with postgraduates, graduate students and undergraduates at the Urals Federal University. 
Table 1: Concept model of value-based management in electric power companies.

\begin{tabular}{|c|c|c|}
\hline $\begin{array}{l}\text { Tiers of the } \\
\text { model }\end{array}$ & $\begin{array}{c}\text { Defining factors, conditions } \\
\text { and spheres of decision making }\end{array}$ & $\begin{array}{l}\text { Key value-creating areas for electric } \\
\text { power companies }\end{array}$ \\
\hline $\begin{array}{l}\text { State } \\
\text { regulation of } \\
\text { electricity } \\
\text { sector }\end{array}$ & $\begin{array}{l}\text { Creating state policy and legal } \\
\text { framework for electricity } \\
\text { sector: WECM, tariff design, } \\
\text { investment opportunities, } \\
\text { customer relations }\end{array}$ & $\begin{array}{l}\text { Proceeding from given first tier } \\
\text { conditions: } \\
\text { - participation in and bigger share of } \\
\text { WECM } \\
\text { - justifying electricity pricing for all } \\
\text { types of electric power companies } \\
\text { with account of investors' and } \\
\text { consumers' interests }\end{array}$ \\
\hline $\begin{array}{l}\text { Creating } \\
\text { company's } \\
\text { intrinsic } \\
\text { (fundamental) } \\
\text { value }\end{array}$ & $\begin{array}{l}\text { - Meeting social requirements } \\
\text { - Appropriate management } \\
\text { system } \\
\text { - Value-based management } \\
\text { strategies } \\
\text { - Investment operations } \\
\text { - Creating investment appeal }\end{array}$ & $\begin{array}{l}\text { - Value-maximizing management } \\
\text { structure } \\
\text { - Creating and implementing } \\
\text { technological and administrative } \\
\text { innovation programmes } \\
\text { - Developing value creation mindset } \\
\text { and motivation for personnel } \\
\text { - Managing capital structure with a } \\
\text { view to capitalization growth } \\
\text { - Decision-making metrics aimed at } \\
\text { maximizing value }\end{array}$ \\
\hline $\begin{array}{l}\text { Stock market } \\
\text { relations }\end{array}$ & $\begin{array}{l}\text { - Taking account of strategic } \\
\text { and portfolio investors' } \\
\text { interests } \\
\text { - Releasing strategic } \\
\text { information on company's } \\
\text { development } \\
\text { - Monitoring changes in } \\
\text { legislation on stock market } \\
\text { and securities }\end{array}$ & $\begin{array}{l}\text { - Continuing analysis of stock market } \\
\text { situation } \\
\text { - Assessing investment benchmarks } \\
\text { and planning to catch up with } \\
\text { industry bests } \\
\text { - Interacting with primary and } \\
\text { secondary stakeholders to meet their } \\
\text { interests }\end{array}$ \\
\hline
\end{tabular}

\section{Results of applying the model}

The most profound research was conducted for OJSC "Territorial generating company N 9 (TGK-9)" [1]. The research takes account of the interplay of the three conceptual tiers of value-based management as indicated in Table 1. A model of development management was designed for TGK-9 that, if implemented, would make it possible to identify value factors for investment appeal and to set strategic priorities in the company's development management. The study looked at various alternative scenarios of the company's market behavior to choose the optimum development option taking into account potential limitations. In this analytical model the factors for managing the value of TGK-9 are related to the bottom line indicator - intrinsic value growth expressed by the economic value added (EVA). To analyze value drivers, production units were geographically identified within the TGK. The investment 
attractiveness of each business unit is shaped, on the one hand, by its investment potential, and on the other hand by the attractiveness of the energy market on the particular territory. As a result, strategic profiles of the units have been developed that contain information for managerial decision making later on. The unit-specific models were combined into a single model of the company that made it possible to identify the key development trends for the TGK ensuring the maximum business value growth. The analysis of the summarized results leads to a conclusion that the highest value-generating effect is a characteristic of the units and regions that constantly work on reliability and development with the involvement of local authorities. Consequently, the TGK's development management system should incorporate a subsystem of timely analytical data sharing with regional authorities. Under the suggested approach, the function is fulfilled by strategic profiles that make it possible to effectively cooperate with government agencies and the tariff regulator in the region.

To prove the efficiency of a value-based management structure, calculations were performed of an increase in a company's valuation as a result of the investment activity of one of its business unit using the case of OJSC "Enel OGK-5" and its subsidiary Sredneuralskaya GRES (SUGRES - Sredneuralskaya thermal power plant). For this purpose, a forecast of EVA was made for SUGRES using a specially designed computational model. Scenarios of investment project development were created for the power plant; after that EnelOGK-5's corporate value growth driven by SUGRES investment activity was estimated.

The calculations showed that the construction of a $410 \mathrm{MW}$ combined cycle gas turbine could considerably impact the valuation of the entire company. For example, if electricity and heating tariffs increased by as little as 10 per cent, the value of OJSC Enel OGK-5 would grow by around 35 per cent thanks to the SUGRES project. A similar method was used to study the feasibility of separating the Karmanovskaya GRES (thermal power plant), that is part of OJSC BGK, into a business unit.

Calculations of how investment projects could boost corporate value growth were also performed for OJSC Sverdlovenergo as a whole and one of its power plants (Krasnogorskaya heat and power plant) at the start of the energy sector reform. The discounted cash flow method was used; various options for the major renovation of fixed assets were devised. The calculations provided analytical information for determining an approximate selling price of the heat and power plant and the market value of OJSC Sverdlovenergo. Despite the uncertainty of future development conditions, the studies showed that even at the initial stage of the privatization of the power sector it was possible to obtain analytical information for decision making.

The state has major influence on the investment appeal of grid companies through price regulation using the Regulatory Asset Base (RAB) model. It provides for a rate of return on investment that guarantees the investor that their money will return with a profit, ensuring a cash inflow into the grid company. The influence of the RAB model was studied for OJSC EESK (Yekaterinburg Grid Company). The research showed that investment inflow coupled with a 
reduction in operational costs that are included in the tariff would make it possible to develop the city power grid at an accelerated rate. It will encourage Yekaterinburg's dynamic development and ensure an acceptable level of investment potential.

The investment appeal of electricity retailers is related to information for stakeholders on creating strategic planning systems, internal control and risk management systems as well as information transparency systems. We would say that building and implementing a development strategy and then making this information available to investors should be the prime priority. Since electricity retailers have a small resource base, the above information sends a signal to investors of a company's improving business reputation. The research showed that it would be reasonable to use the Balanced Scorecard (BSC) method for implementing a company's strategy. The tool was tested for OJSC Sverdlovenergosbyt at the start of its electricity retail business. The method was supplemented with a BSC-based performance measurement model and recommendations to make this information available to stakeholders.

\section{Conclusion}

- $\quad$ At present, the electric power industry is an outsider in terms of investment appeal.

- Managers need to understand how to make their company attractive to investors and how their decisions will affect the company's value dynamics.

- The suggested conceptual model makes it possible to identify and take account of key value-creating factors and to measure a company's performance from this perspective.

- The model is highly applicable to emerging markets where the energy business is yet to take shape.

\section{References}

[1] OJSC Enel OGK-5, http://www.ogk-5.com

[2] Gitelman, L. \& Bokova, O. Business value factors in managing the development of a territorial generation company, [in Russian], UrFU: Yekaterinburg, 2011. 